\title{
The Anglophone Problem in Cameroon: Focus on Education
}

\author{
Jean-Paul Kouega \\ University of Yaounde I, Yaounde, Cameroon \\ Email: jkouega@yahoo.co.uk
}

How to cite this paper: Kouega, J.-P. (2018) The Anglophone Problem in Cameroon: Focus on Education. Open Access Library Journal, 5: e4408.

https://doi.org/10.4236/oalib.1104408

Received: February 5, 2018

Accepted: March 3, 2018

Published: March 6, 2018

Copyright (c) 2018 by author and Open Access Library Inc.

This work is licensed under the Creative Commons Attribution International License (CC BY 4.0).

http://creativecommons.org/licenses/by/4.0/

\begin{abstract}
This article overviews the Cameroon Anglophone educational system from the origins, through the period of Reunification with La République du Cameroun, to the present time. In the process, it highlights the issues that have pushed Anglophone lawyers and teachers to launch a series of protests that have plagued the economy of West Cameroon and seriously affected close to two academic years. Some of the issues identified include the poor state of technical education in the area, the use of French in Anglophone courts and in secondary schools, the difficulty Anglophone students face in tertiary level education where French is dominant, and when writing competitive entrance examinations into professional schools, the programme of which is French-based. Possible solutions to these problems include the creation of technical schools like the former Ombe reference technical school, either the creation of Anglophone professional schools or the transfer of the duties of existing professional schools to university faculties, the re-designing of the English syllabus for francophone secondary schools and that of French for Anglophone schools and, most importantly, the systematic certification of bilingual competence in Cameroon which will, in due course, be made a requirement for recruitment, appointment and posting of civil servants.
\end{abstract}

\section{Subject Areas}

Education, Linguistics

\section{Keywords}

Cameroon, Education, Federalism, Anglophone Problem, Bilingual Competence

\section{Introduction}

The term "Anglophone problem in Cameroon" subsumes the various political, 
economic, and social problems that the former Southern British Cameroons community in Cameroon has been facing since it acceded to independence by joining Francophne Cameroon in 1961. The origins and evolution of this problem are outlined in works like the following: Konings [1], Eyoh [2], Konings [3], Atanga Mufor [4], Achankeng Fonkem [5], Ndi [6], BAPEC [7], Dounge [8], to name only a few. These works have in common the fact that they decry among others, the political marginalisation of Anglophones in the country, the dominance of French, generalized poverty since the creation of the unitary state and the domineering behaviour of Francophone administrators posted to Anglophone Cameroon; they claim that a change in the form of the state from a centralised to a federal system would solve the problem, failing which secession would be the only option left. The present article describes one aspect of this problem i.e. education.

Before independence, an Anglo-Saxon system of education was applied in the territory that was called Southern British Cameroon while a French-based system was applied in Cameroon, a French colony. In 1960, French Cameroon became independent and in 1961, Southern British Cameroons joined French Cameroon and together they formed a two-sate federation, with each federated State maintaining its educational system. This is the background of the two official languages (English and French) used in Cameroon today. In 1972, the two States moved the status of Federation to that of Reunification. As time went by, the Anglophone system, which was rooted in the Anglo-Saxon culture, gradually changed into a French-based system, the workings of which posed a serious problem of understanding to the Anglophone community. In the meantime, the Francophone system opted to promote bilingualism but failed to do so effectively. These two seemingly unrelated outcomes have combined to put Cameroon in a very uncomfortable position. In October 2016, Anglophone lawyers took to the streets partly because a high number of officially monolingual French-speaking lawyers were posted to Anglophone Cameroon, making French the language used in court proceedings involving Anglophone citizens in Anglophone Cameroon and in the write-up of judicial and administrative documents. The following month, Anglophone teachers joined in the strike action partly to protest against an overflow into Anglophone schools of officially monolingual francophone teachers who know very little English and therefore teach Anglophone pupils in French or Pidgin. The Anglophone problem as presented today would surely not have taken its current proportion if these officially monolingual francophone lawyers and teachers posted to West Cameroon were competent bilinguals. This means that part of the Anglophone problem is the failure of the francophone education sub-system of Cameroon to turn out a large number of bilingual citizens. This article considers in turn education in Anglophone Cameroon from the origins up to 1972, the changes in the Anglophone education system from the Reunification period, the consequences of the changes in the education system and possible solutions to the education aspect of the Anglophone problem. 


\section{Education in West Cameroon from the Origins up to 1972}

Anglophone Cameroon corresponds to what is known today as the Northwest and the Southwest regions of the country. During the independence years it was called West Cameroon. Before then it was referred to as Southern British Cameroons. This land became a League of Nations mandated territory under British rule (1922-1946) then a UN Trust Territory under British rule (1946-1961). It gained independence by joining La Republique du Cameroun in a federation in 1961. This caused the country's name to be changed to The Federal Republic of Cameroon. In 1972 the two federal states fused and were renamed the United Republic of Cameroon and in 1984, the country's name was changed back to its initial name i.e. La Republique du Cameroun (the Republic of Cameroon). In 1996, its constitution was revised with the form of the state moving from a highly centralised system to a decentralized system.

When the country was under British rule, primary education was run mainly by Baptist, Catholic and Presbyterian missionaries who built schools and trained teachers to run them. At the secondary level, pupils were admitted into grammar schools, commercial institutions and technical colleges. The common ones were in Buea (Federal Bilingual Grammar School), Mamfe (Government Secondary School), Ombe (Government Technical College (GTC)) and Bambili (Cameroon College of Arts, Science and Technology (CCAST Bambili)). Teacher training colleges were in Kom (Kom Baptist teachers training college (KBTTC)), Kumba (St Francis teachers training college), Bambui (ST Peters Teachers Training College) to name only these. Regarding technical education, the school in Ombe was well-equipped and had a well-designed syllabus. As a result, its graduates were the best in the country. The certificates these pupils sat for were the GCE O' Level and A' Level, the Royal Society of Arts and the City and Guilds. There were no tertiary level institutions and so secondary school leavers had to continue their education in Nigeria, Britain or the USA.

\section{Changes in the Anglophone Education System from the Reunification Period}

In 1972 when the country was renamed the United Republic of Cameroon, many changes were observed. The dominance of missionaries in education began to wane, as Government created primary and secondary schools. Staff from West Cameroon was transferred to East Cameroon: Anglophones were posted to francophone schools and francophones were posted to-or usually appointed in-Anglophone schools and vice versa. Many of the francophone teachers posted to West Cameroon were not competent in English and so they taught in French or Pidgin, especially in technical education. This situation annoyed parents so much so that many transferred their children to government grammar schools, where at least pupils continued to be taught in English. Gradually, English certificates like the Royal Society of Arts (RSA) and the City and Guilds disappeared from the scene; they were replaced by French certificates i.e. the Certi- 
ficat d'Aptitude Professionnelle-CAP (Professional education certification) obtained in Form Four after four years of training, the Probatoire Technique obtained in Lower Sixth Form and the Baccalaureat Technique obtained in Upper Sixth Form. To Government, this was a successful harmonisation of the Anglophone and francophone technical education system.

The direct consequence of this harmonization was insuperable. Courses in Anglophone schools were taught in French and Pidgin. Examinations were set in French and were then translated into English. Usually the translation was poor, which made many pupils fail every year. In technical schools, pupils understood neither the theory taught in French nor the practice in the absence of relevant tools and machines. As a result, disgruntled parents took away their children and registered them in grammar schools where at least they were still taught in English. The pupils who persevered obtained French certificates like Probatoire Technique that had little international cognizance compared to the former RSA or City and Guilds. Worse the few children who eventually completed secondary school had nowhere to go for further education, these certificates they got being meaningless elsewhere in the world including next door Nigeria.

In 1993, another move was made by Government to harmonise the Anglophone general education system with the Francophone one. The move this time was met with strong resistance from the Anglophone community in the country. The city of Yaounde was transformed into a battlefield with soldiers in armoured vehicles chasing the protesters. The resistance was so strong that Government had to yield and therefore create the General Certificate of Education (GCE) Board, which prevented its certificates from falling into oblivion like the City and Guilds certificates.

There was no tertiary education institution in Anglophone Cameroon in those days. Cameroonian pupils who used to go to Nigerian universities were compelled to register in the lone university of Yaounde, where nearly all courses were taught in French. Unlike in Nigeria and other countries where tertiary education is done in university faculties, Cameroon-following France-set up various professional schools like the School of Magistracy, the School of Posts and Telecommunications, the School of Medicine, the Polytechnic School and many others. The entrance examinations into these schools were based on the francophone Baccalaureat syllabus, which made it totally impossible for a GCE holder to pass them. Worse even the few who passed these examinations could not succeed in going through the training because all content courses were taught following a French-designed programme. In some schools like the School of Magistracy, there was a specific Anglophone section where courses were taught in English but with time this section disappeared from the scene for no obvious reason. Anglophones were therefore compelled to follow the same courses taught in French as their francophone mates.

In these schools, courses were taught in French and examinations set in French. Students were authorised to write these examinations in either French or 
English. Unfortunately there was no platform where teachers' competence at marking scripts written in English was assessed. As expected, Anglophones usually failed massively and it was difficult to tell whether their failure was due to poor performance at writing or the markers' poor linguistic competence. As their chances of entering professional schools were limited because of their educational background, Anglophones registered in university faculties where they toiled for many years and eventually graduated. Unfortunately, university certificates did not provide jobs; as a result many Anglophone students-and their francophone brothers alike-relied on their parents to survive and this could go on for over a decade after graduation. Others embarked on petty trades not intended for university degree holders: street vendors, telephone call box operators to name only these.

\section{Consequences of the Changes in the Education System}

The changes in education brought about by Reunification in 1972 turned out to be negative to the Anglophone community. Actually their original system of education was highly technical; many children used to learn practical activities in school including agriculture and, after graduation, they could run a farm if there was no job. Today general education is widespread but its graduates cannot find jobs. Technical education is scarce and the few institutions which offer this type of education lack the appropriate equipment and human resources that can turn out potentially competent workers. It is the sum total of these education problems that has contributed to the current social unrest plaguing the Anglophone regions of Cameroon today. Protesters took to the streets to ask for a return to the federal system that was adopted in 1961 and Government reacted by deploying heavily armed soldiers in Anglophone towns. All types of abuse were recorded on both sides: brutality, inhuman treatment, massive arrest, maiming, deportation, detention of culprits, court actions, and various violations of human rights. Swift protesters made images of serious cases of human rights violation circulate on social media and Government reacted by ordering the complete shutdown of the internet in the whole of West Cameroon to stifle the circulation of worse cases. This pushed the protesters to launch civil disobedience, which the citizens adhered to, knowing fairly well that it would paralyse education as well as the economy of the area.

\section{Solution to the Education Aspect of the Anglophone Problem}

At the level of education, the Anglophone problem would hardly resurface if a number of adjustments and changes are made. First, the syllabi of primary, secondary and tertiary education would have to be modified. Second, the appointment and posting of civil servants would have to be done in a principled way. Third there would be some changes in the structure of the ministries in charge of the youths. Finally certification of bilingual competence would have to be insti- 
tuted and the certificate would have to be valorised. These are considered in turn.

Changes in school syllabi are considered here. There should be changes at the primary, secondary and tertiary level education. Let us consider the primary level first. The present syllabus of primary education ignores national languages. The primary child should learn one official language (not two as is the case now) and be introduced to two indigenous languages i.e. his own mother tongue in the first position and one Cameroon indigenous language of his choice in the second position. This teaching of the indigenous languages will be limited to the acquisition each year of some 200 common vocabulary items like "father", "mother", "sun", "house" etc. and short expressions like "what is your name?", "where are you going?" etc. in each child's two languages. That will give a total of 1200 words in the six primary school years. These words will be recorded on CDs with taxpayers' money and sold at a subsidized price in schools. This exercise will enable Government to draw up a list of those languages which are most often chosen in the second position; from this list will come the ultimate national language of Cameroon. More details on how this selection will be done are presented in separate research works. By getting all Cameroonian languages taught at the same time, Government will be implementing a constitutional provision.

Let us now move on to the secondary level. At this level, the second official language will come in, with French taught to Anglophones and English to Francophones. This time the second official language will not be taught for the sake of teaching as it is the case presently. The outcome of previous teaching has proven to be a sheer wastage of useful resources, most francophones being unable to express themselves in English (see academic works like Sokeng [9] 2011, Yepdia [10] 2013). It will be taught for the learner to get a certificate, the First School Leaving Certificate (FSLC) for francophones and the Certificat d'Etudes Primaires (CEP) for Anglophones. Let us illustrate with the francophone system here, with the understanding that the reverse will apply to the Anglophone system. The English course as from the Sixieme class (Form One) will be taught with the aim to prepare the learner for the First School Leaving Certificate, which is the certificate the primary child gets when he leaves primary school. The syllabus will be drawn from a synthesis of the courses that the Anglophone child learns in primary school (Kouega [11] 2005). This means that the curriculum for English-medium primary schools will be used for the English courses in secondary level French-medium schools. For example, the Sixième English syllabus will be a synthesis of the vocabulary and grammatical structures learnt by the Anglophone child in Class One; that of Troisieme (Form Four) what the Anglophone child learns in Class Six etc. In Seconde, the Francophone child will review what he has learnt in five years in preparation for the First School Leaving Certificate examination. This reasoning can be presented schematically as follows. 


$\begin{array}{cc}\text { French-medium secondary classes } & \text { Corresponding curriculum for English-medium schools } \\ \text { Sixième (Form One) } & \text { Class One } \\ \text { Cinquième (Form Two) } & \text { Classes Two and Three } \\ \text { Quatrième (Form Three) } & \text { Classes Four and Five } \\ \text { Troisième (Form Four) } & \text { Class Six } \\ \text { Seconde (Form Five) } & \text { Review and Writing of the First } \\ \text { Première (Lower Sixth Form) } & \text { School Leaving Certificate Examination } \\ \text { Terminale (Upper Sixth Form) } & \text { Form One } \\ & \end{array}$

The Class One curriculum for English-medium primary schools comprises the following 11 subjects:

- English language

- Mathematics

- French language (N.B. This subject will be replaced by two Cameroonian languages)

- General knowledge

- History

- Geography

- Citizenship (civics, human rights, moral education)

- Science (health education, environmental education)

- Home economics

- National culture (music, drawing, drama, arts and craft)

- Physical education

It is the synthesis of these 10 subjects (as the French language will be introduced at the secondary level) that will be used as the syllabus for the English language course in the Sixieme class in the French-medium schools. Details on how this synthesis will be built into a textbook are provided in separate papers.

There is also a need to implement the proposal put forward in the 1998 Act on Education Guidelines, No 98/004 (Loi No 98/004 d'Orientation de l'Education au Cameroun, 1998) namely that the BEPC examination takes place in Seconde (Form Five) rather than Troisième (Form Four) as is the case today. This move will testify that the francophone system of education has taken at least one feature from the Anglophone system. Actually, all the changes since Reunification aimed at making the Anglophone system look like the francophone one, never the reverse. Still at the secondary level, a few technical schools of the standard of the Ombe reference technical school should be created and negotiations made for the former British certificates known as City and Guilds and the Royal Society of Arts (RSA) to be reinstated.

Third, let us consider the tertiary level. It has been observed that Anglophones who perform very well in the GCE A' Level cannot pass the entrance examinations into most professional schools in Cameroon. This is due to the fact that the examination programmes are based on the Baccalaureat syllabus, which is unfair. Besides the few Anglophones who pass the entrance examinations into these 
schools find it difficult to cope with the courses they offer, as over $90 \%$ of these courses are taught in French. In all major countries in the world, tertiary level education is offered in university faculties, not professional schools as is the case in Cameroon and a few other francophone countries that slavishly follow France's ways of doing things. Two options can be considered to solve this problem: either the English equivalent of each school is created or all professional schools are closed and their duties and budget transferred to university faculties. These schools will therefore be renamed Faculty of Magistracy, Faculty of Administration, Faculty of International Relations to cite only these. Needless to say, courses in all university faculties will have to be taught $50 \%$ in French and $50 \%$ in English if Cameroon is serious about its official French-English bilingualism policy.

Appointment and posting of civil servants are considered next. The appointment and posting of civil servants would have to be done in a principled way: officially monolingual francophone civil servants are to be appointed and posted to a Government service in West Cameroon only when there is no civil servant in that service who is a holder of the First School Leaving Certificate.

Changes in the structure of some ministries are taken up here. There is no Anglophone at the helm of the five ministries in charge of the well-being of the youths in the country. These are: the ministries of higher education, of secondary education, of basic education, of youths and sports, and of employment. The direct consequence of this absence is that the youths tend to lose trust in the Government. There should be some degree of justice and fairness in the choice of the people who are to be appointed to implement Government's policy. In addition there should be two directors in each of these ministries, one in charge of the francophone youths and the other in charge of the Anglophone youths.

Certification of bilingual competence constitutes the last set of changes to make. The perception of bilingual competence will have to change and no one will be begged to attend courses in budget-consuming Pilot Linguistic Centres. Bilingualism is investment; the certification of bilingual competence would have to be instituted and this certificate will have to be valorised. As bilingual competence is a necessary obligation for citizens' peaceful co-existence, francophone civil servants would be required to include a copy of the First School Leaving Certificate (FSLC) in their files for recruitment, promotion or change of grades. Similarly, Anglophones will have to provide the Certificat d Etudes Primaires (CEP). Candidates without this certificate will be recruited, promoted or posted to other localities only when there are no other candidates of equal competence. If these measures were applied, then officially monolingual francophone lawyers and teachers would not have found themselves in Anglophone courts and schools. When this certification proposal is implemented, Government will save much money which is wasted today in Pilot Linguistic Centres which, it is evident, are definitely not productive. The money thus saved will be used to design courses for the teaching of Cameroon indigenous languages and to subsidise the 
purchase of school books.

\section{Conclusion}

This paper has attempted to describe the education aspect of the Anglophone problem in Cameroon, highlighting those areas where the Anglophone community is at a disadvantage. The problems identified can be solved, in most cases, with no special budgetary provision. When systematic certification of bilingual competence will be required for recruitment, appointment and posting of civil servants in Cameroon, crises like the one that is plaguing West Cameroon and affecting national integration and peaceful coexistence today would hardly occur.

\section{References}

[1] Konings, P. and Nyamnjoh, F.B. (1997) The Anglophone Problem in Cameroon. The Journal of Modern African Studies, 35, 207-229.

https://openaccess.leidenuniv.nl/bitstream/handle/1887/4616/ASC-1246231-023.pdf ;sequence $=1$ https://doi.org/10.1017/S0022278X97002401

[2] Eyoh, D. (1998) Conflicting Narratives of Anglophone Protest and the Politics of Identity in Cameroon. Journal of Contemporary African Studies, 16, 249-276. https://doi.org/10.1080/02589009808729630

[3] Konings, P. (2003) Negotiating an Anglophone Identity: A Study of the Politics of Recognition and Representation in Cameroon. Koninklijke Brill, Leiden.

[4] Atanga, M. (2011) The Anglophone Cameroon Predicament. Langaa Research \& Publishing CIG, Bamenda.

[5] Achankeng, F. (2014) The Foumban "Constitutional” Talks and Prior Intentions of Negotiating: A Historico-Theoretical Analysis of a False Negotiation and the Ramifications for Political Developments in Cameroon. Journal of Global Initiatives: Policy, Pedagogy, Perspective, 9, 149.

[6] Ndi, A. (2014) Southern West Cameroon Revisited (1950-1972): Unveiling Inescapable Traps. Langaa RPCIG.

[7] BAPEC (Bamenda Provincial Episcopal Conference) (2017) Memorandum to President Paul Biya on the Current Situation in the Northwest and Southwest Regions. http://www.cameroon-info.net/article/cameroon-bamenda-provincial-episcopal-co nference-memorandum-to-president-paul-biya-on-the-current-situation-in-278001.ht $\underline{\mathrm{ml}}$

[8] Dounge, G. (2017) The Legal Argument for Southern Cameroon Independence. http://www.africafederation.net

[9] Sokeng Piewo, S.C. (2011) The English Language Proficiency of Francophone Secondary School Leavers in Cameroon. Unpublished Ph.D. Thesis, University of Yaounde I, Yaounde.

[10] Yepdia Leundjeu, W. (2013) An Evaluation of Cameroon English Language Textbooks for French-Speaking Secondary Education Schools: A Case Study of Stay Tuned 2nde, Stay Tuned 1ere, Stay Tuned Tle (Form V through Upper Sixth). Unpublished Ph.D. Thesis, University of Yaounde I, Yaounde.

[11] Kouega, J.P. (2005) Promoting French-English Individual Bilingualism through Education in Cameroon. Journal of Third World Studies, 22, 185-196. 